\title{
Implementasi Kemandirian Anak Usia 3-5 tahun di TK Islam Kauman Kota Pekalongan
}

\author{
Ni'matul Ulya ${ }^{1}$, Pedvin Ratna Meikawati ${ }^{2}$, Putri Andanawarih ${ }^{3}$ \\ Email: renex_cubby@yahoo.co.id \\ Akademi Kebidanan Harapan Ibu Pekalongan \\ J1. Sriwijaya No 7 Pekalongan \\ Telp/Fax (0285) 4416108
}

\begin{abstract}
Abstrak
Anak usia 3-5 tahun dianggap sebagai masa anak untuk belajar keterampilan dalam memenuhi keinginannya secara mandiri. Anak berusia 3-5 tahun harus dapat melakukan aktivitas, seperti makan dan minum sendiri, mandi dan berpakaian sendiri, menyisir rambut, berjalan, berlari, dan mengambil benda yang diperlukannya sendiri. Faktor keluarga sangat berpengaruh terhadap pembentukan kemandirian pada seorang anak. Berdasarkan hasil wawancara pada 10 orang ibu (wali murid) di salah satu TK swasta di Kota Pekalongan didapatkan 2 ibu mengatakan bahwa anaknya tidak pernah bermain di luar rumah, jarang sosialisasi dan malu. Sebanyak 6 ibu mengatakan anaknya belum bisa memakai baju sendiri dan kadang makan masih disuapin orang tuanya dan 2 ibu mengatakan anaknya sangat manja, tidak mau membereskan mainanya. Kegiatan pengabdian kepada masyarakat yang dilakukan di TK Islam Kauman bertujuan memberikan keterampilan kepada anak-anak usia 3-5 tahun untuk dapat melakukan kegiatan sehari-harinya secara mandiri. Metode yang digunakan dalam kegiatan ini adalah dengan edukasi dan demonstrasi. Hasil yang diperoleh sebanyak 48 siswa sudah bisa memakai baju mandiri, 39 siswa sudah bisa melipat baju sendiri, 26 siswa sudah bisa mengancingkan baju sendiri, dan 27 siswa memakai kaos kaki secara mandiri.
\end{abstract}

Kata Kunci : Anak Usia 3-5 tahun, Kemandirian.

\begin{abstract}
Children aged 3-5 years are considered as a child's age to learn skills to fulfill their desires independently. Children aged 3-5 years must be able to do activities, such as eating and drinking by themselves, bathing and dressing themselves, combing hair, walking, running, and taking things that they need themselves. Family factors are very influential on the formation of independence in a child. Based on the results of interviews with 10 mothers (guardians of students) in one private kindergarten in Pekalongan City, it was found that 2 mothers said that their children had never played outside, rarely socialized and were ashamed. A total of 6 mothers said their children could not wear their own clothes and sometimes their parents still fed the food and 2 mothers said their children were very spoiled, did not want to make up their toys. The community service activities conducted at the Kauman Islamic Kindergarten aim to provide skills to children aged 3-5 years to be able to carry out their daily activities independently. The method used in this activity is education and demonstration. The results obtained as many as 48 students were able to wear clothes independently, 39 students were able to fold their own clothes, 26 students were able to button their own clothes, and 27 students were wearing socks independently.
\end{abstract}

Keywords: Children 3-5 years old, Independence.

\section{Pendahuluan}

Pembangunan kesehatan sebagai bagian dari upaya kesehatan anak dilakukan sedini mungkin sejak anak-anak masih dalam kandungan. Upaya kesehatan yang dilakukan sejak anak masih dalam kandungan sampai usia lima tahun pertama kehidupannya ditujukan untuk mempertahankan kelangsungan hidupnya sekaligus meningkatkan kualitas hidup anak agar mencapai tumbuh kembang yang optimal baik fisik, mental, emosional, maupun sosial serta memiliki intelegensi 
majemuk sesuai dengan potensi genetiknya $^{[1]}$.

Pencapaian suatu kemampuan pada setiap anak berbeda, namun demikian ada patokan umur tentang kemampuan apa saja yang perlu dicapai seorang anak pada umur tertentu. Adanya patokan ini dimaksudkan agar anak dilatih berbagai kemampuan untuk dapat mencapai perkembangan yang optimal ${ }^{[2] .}$

Masa anak merupakan masa pertumbuhan dan perkembangan yang dimulai dari bayi (0-1 tahun), usia bermain atau toddler (1-3 tahun), pra sekolah (3-5 tahun), usia sekolah (5-11 tahun) hingga remaja (11-18 tahun). Rentang ini berbeda antara anak satu dengan anak yang lain mengingat latar belakang anak yang berbeda misalnya kondisi fisik anak ketika lahir.

Anak yang berusia 3-5 tahun dikategorikan dalam masa kanakkanak awal. Pada masa ini, pertumbuhan, seperti fisik, kecerdasan, keterampilan motorik dan sosial berjalan demikian pesatnya. Masa ini juga merupakan masa kritis yang akan menetukan hasil proses tumbuh kembang anak selanjutnya. Masa kanak-kanak awal juga merupakan masa dimana ketergantungan secara praktis sudah dilewati diganti dengan mulai terbentuknya kemandirian.

Menurut John Locke dengan teori tabularasnya menyatakan, bahwa pada permulaannya, jiwa anak itu adalah bersih, bagaikan selembar kertas putih, yang kemudian sedikit demi sedikit terisi oleh pengalaman atau empiri. Dengan kata lain, akan menjadi apa anak tersebut tergantung dari lingkungan yang memberi warna pada kertas putih tersebut. Dengan demikian kebiasaan-kebiasaan tingkah laku secara fisik maupun psikis yang berkembang pada anak sangat dominan dipengaruhi oleh bagaimana cara kita memperlakukan anak ${ }^{[3]}$.

Keluarga merupakan lingkungan hidup pertama dan utama dalam kehidupan setiap orang, Hal tersebut sangat berpengaruh terhadap pembentukan kemandirian pada seorang anak.Salah satu kondisi keluarga yang mempengaruhi kemandirian seorang anak adalah pola pendidikan keluarga. Pola pendidikan keluarga yang dimaksud adalah cara kedua orang tua mendidik anaknya atau dapat pula disebut sebagai pola asuh orang tua [4].

Kemandirian adalah suatu sikap individu yang diperoleh secara kumulatif selama perkembangan, dimana individu akan terus belajar untuk bersikap mandiri dalam menghadapi berbagai situasi lingkungan, sehingga individu pada akhirnya akan mampu berpikir dan bertindak sendiri dengan kemandiriannya. Istilah kemandirian pada anak umumnya dikaitkan dengan kemampuan untuk melakukan segala sesuatunya sendiri (6).

Menurut Soetjiningsih dalam Mu'tadin (2002), ada beberapa faktor yang mempengaruhi tingkat kemandirian anak, yaitu :

a. Faktor Internal adalah faktor yang ada dari diri anak itu sendiri yang meliputi Emosi dan intelektual.

b. Faktor Eksternal adalah hal-hal yang datang atau ada dari luar diri anak itu sendiri yang meliputi lingkungan, pekerjaan ibu, stimulasi, pola asuh, cinta dan kasih saying, interaksi anak dan ibu serta pendidikan ibu.

Menurut Yusuf (2002), menumbuhkan kemandirian pada individu sejak usia dini sangatlah penting karena dengan memiliki kemandirian sejak dini, anak akan terbiasa mengerjakan kebutuhannya sendiri. Secara naluriah, anak 
mempunyai dorongan untuk berkembang dari posisi dependent (ketergantungan) ke posisi independent (bersikap mandiri). Anak yang mandiri akan bertindak dengan penuh rasa percaya diri dan tidak selalu mengandalkan bantuan orang dewasa dalam bertindak ${ }^{[3]}$.

Robert Havighurst dalam Mu'tadin (2002) menyebutkan bahwa kemandirian terdiri dari beberapa aspek, yaitu : aspek intelektual, aspek social, aspek sosial, dan aspek ekonomi.

Berdasarkan wawancara kepada 10 ibu murid di TK Alfikri Kota Pekalongan pada tanggal 6 Maret 2018 menyatakan bahwa 2 orang (20\%) mengasuh anaknya dengan pola asuh otoriter, jadi dalam segala hal yang dilakukan anaknya selalu diatur oleh orang tuanya sehingga 2 anak selalu takut dalam membantu pekerjaan di rumah, takut untuk bermain ke rumah tetangga dan malu untuk berdandan sendiri.

Ibu yang mengasuh anaknya dengan cara demokratis yaitu 6 orang $(60 \%)$, yaitu mereka memberikan kebebasan yang bertanggung jawab kepada anaknya sehingga anaknya dapat melakukan kegiatannya secara mandiri tetapi 3 anak masih belum bisa memakai baju, memakai baju dan kadangkadang makan masih disuapin oleh orang tuannya.Ibu yang mengasuh anaknya secara permisif sebanyak 2orang $(20 \%)$ mengatakan sangat memberikan kebebasan tanpa terkontrol kepada anaknya sehingga 2 anak menjadi manja, tidak mau membereskan mainannya di rumah dan tidak mau mencuci tangan dan kaki apabila mau makan.

Berdasarkan latar belakang diatas, melalui kegiatan pengabdian kepada masyarakat sebagai wujud Tri Dharma Perguruan Tinggi, beberapa dosen ikut berperan secara aktif dalam memberikan edukasi dan demonstrasi kepada siswa TK A dan TK B yang bertujuan untuk lebih meningkatkan pemahaman dan implementasi kemandirian sesuai dengan umur di TK Islam Kauman Pekalongan.

\section{Metode}

Kegiatan pengabdian masyarakat ini dilaksanakan di TK Islam Kauman Pekalongan pada bulan Maret 2018. Sasaran dari kegiatan ini adalah seluruh siswa TK A dan TK B yang berjumlah 56 siswa.

Metode yang dikembangkan dalam kegiatan ini adalah edukasi dan demonstrasi. Siswa TK diberikan edukasi dengan menampilkan video kemandirian anak usia dini. Untuk lebih meningkatkan pemahaman dan implementasi kemandirian, tim melakukan demontrasi melalui permainan.

Demonstrasi yang dilakukan meliputi cara memakai baju, cara melipat baju, cara memakai kaos kaki dan mengancingkan baju secara mandiri. Pada kegiatan ini, siswa diminta untuk melakukan semuanya secara sendiri. Bagi siswa yang bisa melakukan semuanya mandiri, diberikan hadiah menarik yang sudah dipersiapkan oleh tim.

\section{Hasil Dan Pembahasan}

Kegiatan pengabdian masyarakat Implementasi Kemandirian Pada Anak Usia 3-5 tahun dilakukan terhadap siswa TK Islam Kauman yang berjumlah 56 siswa. TK Islam Kauman merupakan salah satu TK swasta yang terletak dekat dengan alun-alun Kota Pekalongan. Pengabdian kepada masyarakat ini merupakan tindak lanjut dari hasil penelitian yang telah dilakukan sebelumnya oleh tim pengabdian masyarakat ini.

Antusiasme peserta dalam kegiatan ini cukup tinggi terbukti dengan banyak anak yang tunjuk jari dan saling berebut untuk praktik melakukan cara melipat baju, 
memakai kaus kaki, memakai dan mengancingkan baju.

Tabel 1 Karakteristik Demografi Siswa

\begin{tabular}{ccc}
\hline $\begin{array}{c}\text { Karakteristik } \\
\text { Demografi }\end{array}$ & $\mathbf{N}$ & $\mathbf{\%}$ \\
\hline Umur (tahun) & & \\
$3-4$ & 7 & 12,5 \\
$4-5$ & 23 & 41,1 \\
$5-6$ & 26 & 46,4 \\
\hline Total & 56 & 100 \\
\hline Jenis Kelamin & & \\
Laki-laki & 25 & 44,6 \\
Perempuan & 31 & 55,4 \\
\hline Total & 56 & 100 \\
\hline Pendidikan Ibu & & \\
Tamat SMP & 13 & 23,2 \\
Tamat SMA/SMK & 37 & 66,09 \\
Tamat D1/D3 & 4 & 7,14 \\
Tamat S1 & 2 & 3,57 \\
\hline Total & 56 & 100 \\
\hline
\end{tabular}

Tabel 1 menunjukkan siswa yang menjadi sasaran kegiatan ini kebanyakan berada dalam rentang umur 4-5 tahun sebanyak $41,1 \%$ dan rentang umur 5-6 tahun sebanyak $46,4 \%$. Lebih dari separo siswa berjenis kelamin perempuan $(55,4 \%)$ dan tingkat pendidikan ibu mayoritas berpendidikan terakhir tamat SMA/SMK sejumlah $66,09 \%$.

Sebagian besar siswa berada dalam rentang umur 4-5 tahun dan 5-6 tahun. Hal ini sesuai dengan Permendikbud No 14 tahun 2018 dimana persyaratan usia anak bisa masuk TK adalah usia 4-5 tahun untuk kelompok A dan usia 5-6 tahun untuk kelompok B ${ }^{[1]}$. Selain itu, Pendidikan ibu dalam perawatan anak akan mempengaruhi kesiapan mereka menjalankan peran sebagai orang tua. Semakain tinggi pendidikan ibu semakin tinggi pula pengetahuan dalam berfikir termasuk pengtahuan tentang cara mendidik dan mengasuh anak yang benar dan tidak menyimpang ${ }^{[2]}$.
Tabel 2 Hasil Kemandirian Siswa "Cara Memakai Baju"

\begin{tabular}{ccc}
\hline $\begin{array}{c}\text { Cara Memakai } \\
\text { Baju }\end{array}$ & $\mathbf{N}$ & $\mathbf{\%}$ \\
\hline Mandiri & 48 & 85,7 \\
Dengan bantuan & 8 & 14,3 \\
\hline Total & 56 & 100 \\
\hline
\end{tabular}

Tabel 2 menunjukkan mayoritas siswa sudah bisa memakai baju secara mandiri sebanyak $85,7 \%$. Kemadirian siswa setelah diberikan demonstrasi cara memakai baju terjadi peningkatan yaitu sebanyak 48 siswa mampu untuk melipat baju secara mandiri. Sedangkan 8 siswa masih harus diberikan bantuan. Melatih kemandirian anak perlu dilakukan sepanjang hari untuk mendorong anak bertindak mandiri. Kegiatan memakai baju merupakan aktivitas seharai-hari yang seharunya mampu dilakukan anak usia pra sekolah ${ }^{[3]}$.

Tabel 3 Hasil Kemandirian Siswa "Cara Melipat Baju"

\begin{tabular}{ccc}
\hline CaraMelipat Baju & $\mathbf{N}$ & $\mathbf{\%}$ \\
\hline Mandiri & 39 & 69,6 \\
Dengan bantuan & 17 & 30,4 \\
\hline Total & 56 & 100 \\
\hline
\end{tabular}

Tabel 3 menunjukkan mayoritas siswa sudah bisa melipat baju secara mandiri sebanyak 69,6\%. Dari hasil tersebut dapat terlihat siswa mampu menirukan cara melipat baju yang telah didemontrasikan, meskipun ada beberapa siswa yang masih meminta bantuan.

Tabel 4 Hasil Kemandirian Siswa "Mengancingkan Baju"

\begin{tabular}{ccc}
\hline $\begin{array}{c}\text { Mengancingkan } \\
\text { Baju }\end{array}$ & $\mathbf{N}$ & $\mathbf{\%}$ \\
\hline Mandiri & 26 & 46,4 \\
Dengan bantuan & 30 & 53,6 \\
\hline Total & 56 & 100 \\
\hline
\end{tabular}


Tabel 4 menunjukkan sebagian besar siswa belum dapat mengancingkan bajunya secara mandiri, masih butuh bantuan dari orangtua maupun gurunya sebanyak $53,6 \%$.

Kegiatan mengancingkan baju lebih banyak anak tidak mampu melakukan secara mandiri meskipun telah dilakukan demonstrasi, hal ini dikarenakan alat peraga memnggunakan seragam siswa itu sendiri yang memiliki kancing dengan ukuran kecil

Tabel 5 Hasil Kemandirian Siswa "Memakai Kaos Kaki"

\begin{tabular}{ccc}
\hline $\begin{array}{c}\text { Memakai Kaos } \\
\text { Kaki }\end{array}$ & N & \% \\
\hline Mandiri & 27 & 48,2 \\
Dengan bantuan & 29 & 51,8 \\
\hline Total & 56 & 100 \\
\hline
\end{tabular}

Tabel 5 menunjukkan keseimbangan jumlah siswa dalam kemandirian memakai kaos kaki. Sebanyak 48,2\% siswa sudah bisa memakai kaos kaki sendiri dan $51,8 \%$ masih dengan bantuan orangtua ataupun gurunya.

Kegiatan memakai kaos kaki, ditemukan masih banyak anak yang belum mampu melakukan secara mandiri, sehingga mereka meminta bantuan dalam membedakan kaus kaki kanan dan kiri serta memposisikan kaos kaki dengan benar.

\section{Kesimpulan}

Pelaksanaan kegiatan pengabdian kepada msayarakat "Implementasi Kemandirian Anak Usia 3-5 Tahun Di TK Islam Kauman Kota Pekalongan" dapat diterima oleh mitra dan terkoordinasi dengan baik. Kemandirian anak perlu diajarkan sejak dini dan dilakukan setiap hari, sehingga mampu mendorong anak bertindak mandiri. Ada perbedaan antara melakukan untuk (doing to) dengan melakukan bagi (doing for) anak. Perlu menahan diri untuk menunggu anak menaikkan resleting, mengerti kapan anak perlu dibantu tanpa diambil alih, tidak berbicara terlalu banyak saat anak sedang berusaha belajar.

Kegiatan pengabdian kepada masyarakat ini dianggap sangat membatu oleh guru dan orang tua murid. Orang tua murid menganggap pengajaran kemandirian yang diberikan oleh tim lebih berhasil daripada bila dilakukan oleh orang tua langsung dirumah, karena anak lebih bergantung pada orang tua.

\section{Daftar Pustaka}

[1] Departemen Kesehatan RI. $2010 . \quad$ Pemantauan

Pertumbuhan Balita. Jakarta: RI

[2] Santoso, Soegeng. 2004. Kesehatan dan gizi. Jakarta : Rineka Cipta.

[3] Yusuf, Syamsu. (2011). Psikologi Perkembangan Anak dan Remaja. Bandung: ROSDA

[4] Hakim. 2002. Psikologi Pendidikan. Bandung : Rosda Karya.

[5] Kemendikbud. 2018. Peraturan Menteri Pendidikan dan Kebudayaan RI Nomor 14 Tahun 2018. Jakarta.

[6] Noorlaila, I. (2010). Panduan Lengkap Mengajar PAUD. Yogyakarta: Pinus Book Publisher.

[7] Sa'diyah, Rika. "Pentingnya melatih kemandirian anak." Kordinat| Jurnal Komunikasi Antar Perguruan Tinggi Agama Islam 16.1 (2017): 31-46. 